\title{
THE EFFECT OF BETENGAN GAME ON THE SOCIO-EMOTIONAL SKILLS OF PRE-SCHOOL CHILDREN
}

\author{
Sri Maryati Deliana \\ Psychological Department, Universitas Negeri Semarang \\ Semarang, Indonesia \\ maryatideliana@mail.unnes.ac.id \\ Ummi Khaedaroh Jazilah \\ Primary Education Department, Post-Graduate Program, Universitas Negeri Semarang \\ Semarang, Indonesia \\ Hartono \\ Art Department, Universitas Negeri Semarang \\ Semarang, Indonesia
}

\begin{abstract}
This research is aimed at analyzing differences in children's socio-emotional development prior to and after playing Betengan game at TK Al Maghfiroh Semarang and analyzing the measure of socio-emotional skills development after playing Betengan game at TK Al Maghfiroh Semarang. This research employed the quantitative approach using experimental method. The type of experiment used was one group pretest posttest. The samples were 30 anak.

Results show Sig. $(2$ tailed $)<0.05$, at $0.000<0.05$. Hence it is concluded that there is a difference in the result of both pre-test and post-test for children's socio-emotional skills. The value for this effect of Betengan game on children's socioemotional skills is at calculated $\mathrm{r} 2=0.773 \times 0.773=0.597$ atau $59.7 \%$. This means that the effect of Betengan game on children's socio-emotional skills at TK Al Maghfiroh is an improvement of 59.7\%. Therefore, this research concludes that there is a difference in children's socio-emotional skills prior to and after playing Betengan game. This difference in an increase of $59.7 \%$ in children's socio-emotional skills.
\end{abstract}

Keywords- Betengan game, kindergarten, socio-emotional.

\section{INTRODUCTION}

In their early years, children tend to act a bit rude socially as they do not yet understand how to behave properly in a social setting [1]. Until they reach the age of 5 , children will have to at least undergo stages of habituation, knowing rules, getting to know discipline, and building a basic understanding of by transitioning from concrete objects to abstract ideas, from norms to recognizing rules and regulation, from main things to detailed items.

Habituation starts since the day a baby was born as he/she started to interact with his/her surroundings. Habituation starts from the family (parents), the neighborhood with his/her peers, and at school. Those settings affect the way children get used to certain behaviors. Instilling behaviors in the family is very important as to prepare children to have empathy, courtesy, sympathy, tolerance, mutual respect, and other social skills in their later lives.

Habituation is a process of instilling attitude, and attitude tends to be permanent and becomes automatic with repetitive conditioning. An attitude that has become a habit has certain characteristics: it is relatively permanent, it does not require high thinking function, such as when we say greetings, we do not need to think hard, we only have to copy and memorize some expressions, it is not a result of maturing process, it is a result of learning or experience, and it is a repetitive response to the same stimulus [2].

One of the development aspects that should be the concern for all teachers and parents is children's socio-emotional skills development. Muhibin [3] mentioned that children's social development is the process of forming a social self (an individual in a society), that is an individual in the family, culture, nation, and so on. Socio-emotional development is one of the aspects of development in Pre-School children. Children's socio-emotional development starts egocentrically from themselves as they view themselves from their own perspective, then to selfconcept and self-control, and gradually towards interaction with others. Examples for this can be seen when children feel happy as they play with their peers, when they can socialize with their friends, and when they can get along well with new friends, when they feel empathy for their sick friends, or when they can help their friends who are in need [4]. Yusuf [5] stated that social development is the achievement of social relations.

Developing habituation for attitude can be carried out with conditioning. All sorts of purposes and functions of teaching dancing for instance can be achieved with proper conditioning such as group play conditioning that is aimed at improving the socialemotional skills of children, as it provides socioemotional experiences to children, as well as instilling 
moral and emotional values. A proper conditioning does not only mean focusing on end result or the form of dance to master, but also emphasizing the process and creativity experienced by children. Goleman [6] stated that emotion refers to, certain biological and psychological sequences that tend to manifest in an action.

The real condition at $\mathrm{TK} \mathrm{Al}$ Maghfiroh Semarang is that some children have problems with their socio-emotional development. Some of these problems include being temperamental and often initiate arguments. Some others feel shy and awkward upon being asked to perform before the class. In another case, some children feel worry and uncomfortable when their parents leave them at school.

Examples of other socio-emotional problems include children's inability to get along with their peers, being introvert, being excluded by their peers, and children with certain unpleasant characters. Come children are also found to be aggressive toward others, and are unable to cooperate.

TK Al Maghfiroh is aimed at contributing to the education in Indonesia. TK Al Maghfiroh does have some advantages that still need to be improved and perfected to its ideals. One of the challenges to do so is dealing with the real issue of socio-emotional developments in children studying there by creating certain conditions that help children overcome their difficulties.

The above mentioned findings lead the researchers to study the process of children's socio-emotional development using traditional games. Traditional games are typical of certain regions that also reflect those regions' cultures. These games are some of the national cultural heritage that is not only fun but also meaningful to children's growth. Traditional games allow children to learn knowledge, emotional development, social interaction, motoric abilities, while preserving local cultures.

Hurlock [7] argued that playing games is any activity for fun, without taking the end result into account. Traditional games in Indonesia vary greatly, depending on the region, geographical location, and local tradition and culture. Despite the fact that some games are the same, the traditional, culture, and social environment of each region affect the way the games are played. However, people are not more addicted to technologies as modernization penetrates traditional lives. Children ted to leave traditional games as practical options like Play Station consoles, online games, and gadgets attract their attention. These types of games do have negative effects for their emotional development.

That problem is also evident at $\mathrm{TK} \mathrm{Al}$ Maghfiroh Semarang. Children no longer play traditional group games like hopscotch, Betengan, and hide and seek. Hopscotch is no longer a trend as many houses no longer have adequate lawn. What children will find once they open the fence of their home is the alleys that lead to the main road. Hence, they are at risk of being hit by vehicles if they try to play hopscotch in those alleys. This case is the same with Betengan that requires a spacious lawn. At $\mathrm{TK} \mathrm{Al}$ Magfiroh Semarang, this is simply impossible as what they have is the edges of the Eastern Flood Canal.

The game that is evidently extinct for children is hide and seek in the evening. Right after dusk, children are now busy reciting Al-Qur'an or studying. Afterwards, they are glued to their TV programs or applications in their gadget. These mean that traditional games are disappearing from children's life. The Directorate of Cultural Values [8] stated that traditional games have inherent values that can serve as educational means for children. Traditional games that used to color children days are now forgotten, wiped away by the advent of new technologies. Children who used to play games in their lawn, no longer do so, especially children in cities.

One of the most popular traditional games is Betengan. Betengan is a group game that requires swiftness, speed, and strategy. This game is a good sport. Players have to run to keep their fort (beteng) and capture the enemies. The aim of the game is to capture an opponent's fort. Children playing this game are in direct contact with their peers. The benefit of playing, both in a group and individually, is explained by Trijanta in Kartini Kartono [9]. A group game requires proper team work. A group game helps develop social sense, cooperation, responsibility, trust, and the likes.

In a group game children learn to observe both their rights and responsibilities. Children learn to share toys, take turns, help each other, and to be independent too. A group game may lead to arguments and fights. But these are inherent aspects of cooperation that will actually help children to adjust as each child is a unique individual.

Proper help and guidance will help children understand that arguments and fights help them learn to control emotion and elementary moral concepts of: right, wrong, good, bad, honesty, fairness, etc. A group game allows children to learn to adapt themselves as there are many children involved and numerous items must be used together.

Children will feel pride to have their own groups and to be important members of these groups. Gradually, group games significantly affect social attitudes in children. Children will learn to adapt their attitudes for both their won and their group's shake [10].

Children need to cooperate with their peers to develop aspects of their socio-emotional, educational, nutritional, and spiritual developments. All of those aspects are interrelated. Children's development is a process of changing attitude from simple to complex, from immature to mature. Children learn higher levels of movements, thoughts, feelings, and interactions with others and the surroundings. 
Those elaborations lead to the outline of this research: 1) what are the differences in socioemotional development of children prior to and after Betengan game at TK Al Maghfiroh Semarang? And 2) what is the degree of socio-emotional development in children with Betengan game at TK Al Maghfiroh Semarang?

\section{METHOD}

This is an experimental research using the pre experimental design type with one group pre-test and post-test [11].

Table 1. Design of experimental research.

\begin{tabular}{|l|l|l|l|}
\hline Group & Pre-test & Treatment & Post-test \\
\hline Experiment & $\mathrm{O} 1$ & $\mathrm{X} 1$ & $\mathrm{O} 2$ \\
\hline
\end{tabular}

$$
\begin{aligned}
& \mathrm{O} 1=\text { Pre-test } \\
& \mathrm{O} 2=\text { Post-test } \\
& \mathrm{X} 1=\text { treatment with Betengan }
\end{aligned}
$$

The population of this research was 30 pupils of Class B at TK Al Maghfiroh Gayamsari Semarang. Meanwhile, the variables are both dependent and independent variables. The independent variable is traditional group game, whereas the dependent variable is socio-emotional achievement in children.

The outline of this research is based on socioemotional indicators for children aged 5-6.

The data collection technique employed was 1) observations of pre-test and post-test activities. These observations were meant to replace tests that children may otherwise had to undergo.

The data analysis technique was correlation test for Product Moment and Paired sample t-test.

\section{III.RESULT AND DISCUSSION}

Results shown from this research include differences in socio-emotional skills from pre-test and post-test, and also improvement in socio-emotional skills.

\section{Differences in Socio-Emotional Skills}

The early condition of socio-emotional development in children at TK Al Maghfiroh Semarang as revealed in the survey show all sorts of phenomena such as: low cooperation, less tolerance, lack of emotional expression, lack of obedience with the rules and disciplines, lack of effort, and less appreciation toward the others' ability. [12] explained the need for socio-emotional skills improvement, especially empathy in children.

Should those situations are left as they are, classes will be less conducive, children will have difficulties to participate in habitation, children will also experience more pressure in learning as their peers are not tolerant, and there will not be any discipline and order. Furthermore, possible consequences for negligence of those issues may come in the form of imbalanced socio-emotional development in children, and less effective learning as teachers have to also deal with troublesome kids. [13] explained that the socio-emotional issue is about instilling morality and empathy toward others in children. The value of empathy toward other people's welfare is manifested in the way children interact with their peers.

Earlier results in 30 pupils of $\mathrm{TK} \mathrm{Al}$ Maghfiroh Semarang indicate that globally, $0 \%$ of students show very high socio-emotional skills, $0 \%$ of students show high socio-emotional skills, $30 \%$ of students show medium socio-emotional skills, $70 \%$ of students show low socio-emotional skills. The following table show further details of this statement:

Table 2. Socio-emotional conditions in children.

\begin{tabular}{|l|l|l|c|c|c|c|}
\hline Score & Value & \multirow{2}{*}{ Criteria } & \multicolumn{2}{|c|}{ Pre } & \multicolumn{2}{|c|}{ Post } \\
\cline { 4 - 7 } & Range & & $\sum$ & $\%$ & $\sum$ & $\%$ \\
\hline 4 & $21-24$ & Very high & 0 & 0 & 25 & 83 \\
\hline 3 & $16-20$ & High & 0 & 0 & 5 & 17 \\
\hline 2 & $11-15$ & Medium & 9 & 30 & 0 & 0 \\
\hline 1 & $6-10$ & Low & 21 & 70 & 0 & 0 \\
\hline
\end{tabular}

After treatment, socio-emotional skills in children improved. Table 1 depicts global values for children who are $83 \%$ have very high socio-emotional skills, $17 \%$ have high socio-emotional skills, $0 \%$ have medium socio-emotional skills, and $0 \%$ have low socio-emotional skills.

Other than calculating the pre and post socioemotional skills frequency, this research also carried out another calculation with the difference test method. This method employed the Paired sample ttest technique.

Table 3. Results of paired mean test Paired Sample Statistics

\begin{tabular}{|c|c|r|r|}
\hline \multicolumn{4}{|c|}{ Paired Sample Statistics } \\
\hline \multirow{2}{*}{ Pair 1 } & & Mean & N \\
\cline { 2 - 4 } & Post & 21.47 & 30 \\
\cline { 2 - 4 } & Pre & 9.53 & 30 \\
\hline
\end{tabular}

Table 3 shows that pre-test value of 9.53 increases to 21.47. Therefore, children improve their socioemotional skills by 11.94 points. Other than the mean result for paired sample test, the value for calculated $t$ and Sig. Result are also known, as depicted in Table 4. 
Table 4. Results of paired sample t-test Paired Sample Test

\begin{tabular}{|c|c|c|c|c|}
\hline \multicolumn{5}{|c|}{ Paired Sample Test } \\
\hline & Mean & $\mathrm{t}$ & Df & $\begin{array}{c}\text { Sig. } \\
\text { (2-tailed) }\end{array}$ \\
\hline & & & & \\
\hline post - pre & 11.933 & 48.874 & 29 & .000 \\
\hline
\end{tabular}

For the testing criteria, if significance is $>0.05$, then $\mathrm{H} 0$ is accepted, and if significance is $<0.05$, then $\mathrm{HO}$ is rejected. $\mathrm{H} 0$ states that there is no difference in the mean pre-test and post-test results of children's socio-emotional skills. Ha states that there is a difference in the mean pre-test and post-test results of children's socio-emotional skills. Results of Sig. (2 tailed) $<0.05$. That is $0.000<0.05$. Hence, it is concluded that there is a difference in the mean pretest and post-test results of children's socio-emotional skills.

For the testing criteria, if tcalculated $<$ ttable, then $\mathrm{H} 0$ is accepted, whereas if tcalculated $>$ ttable, then $\mathrm{HO}$ is rejected. Table 4.5 reveals values of tcalculated $=48.874$ and ttable $=2.045$. These show that there is a difference between pre and post treatment values in children. Therefore, it is inferred that there Betengan game does influence children's socio-emotional skills.

After two testing to see differences of pre and post treatment abilities, it is concluded that children have differences in socio-emotional skills after they play Betengan game.

\section{Improvement of Socio-Emotional Skills}

Playing is very much needed in $\mathrm{TK} \mathrm{Al}$ Maghfiroh Semarang as children are in the stage of motoric and socio-emotional development that requires them to play and hence, an outdoor playing ground. So far, difficult children are only facilitated to play indoor by their teachers. Outdoor activities are only carried out once in a while by making use of an available plot of land around $250 \mathrm{~m}$ away from the school. The problem teachers face there now is the limited number of games and the limited space available. Therefore, teachers, parents and the school headmaster are trying to work on a way out to allow conditioning for proper children playing and learning facilities.

Teachers employ different methods to deal with socio-emotional problems that children face. These methods are specifically designed to meet a child's unique need. For instance, when a child wants to get attention from his/her teacher, or he/she simply wants to get a help in dealing with his/her troublesome friend. In these situations teachers employ different unique strategies as required.

Attempts required to develop group game activities at TK Al Maghfiroh Semarang are part of the consequence of a pre-school children institution.
Other than lack of playing ground and facilities, administrative issues there are also subject to improvement.

TK Al Maghfiroh Semarang requires more playing ground, both indoor and outdoor, with the growing number of students there. This is also supported by the fact that TK Al Maghfiroh Semarang recently applies the new national education system mandated for Gayamsari sub-district Semarang. Hence, as the first measure, TK Al Maghfiroh Semarang already sets a program outline for both indoor and outdoor activities.

The aforementioned explanations reveal that playing and conditioning at TK Al Maghfiroh Semarang are not yet equipped with proper facilities, but nonetheless, teachers and the headmasters have strived to develop children socio-emotional and motoric skills there. Prior to testing to find out the level of improvement in socio-emotional skills, a normality test was carried out. This test is meant to see the level of data normality. If the level is normal then a Moment Product Correlation test can ensue. Normality test is a common procedure before a statistical method is employed. It is a part of conditions for data analysis and is known as the classic assumption. It is aimed at figuring out whether data distribution follows the pattern of normal distribution or not. Normality test is carried out using the statistical test of Kolmogorov-Smirnov. In order to determine whether some data are normal or not, the Asymp. Sig. Values in Kolmogorov-Smirnov method can be utilized. According to, the criteria for data distribution normality is when the KolmogorovSmirnov significance test is $>0.05$. If the Kolmogorov-Smirnov significance test value is < 0.05 , then the data is not normally distributed.

Table 5. Results of Kolmogorov-Smirnov test. One-Sample Kolmogorov-Smirnov Test

\begin{tabular}{|c|c|r|}
\hline \multicolumn{3}{|c|}{ One-Sample Kolmogorov-Smirnov Test } \\
\hline & pre & \multicolumn{1}{c|}{ Post } \\
\hline $\mathrm{N}$ & 30 & 30 \\
\hline Kolmogorov-Smirnov Z & .725 & 1.102 \\
\hline Asymp. Sig. (2-tailed) & .670 & .176 \\
\hline
\end{tabular}

a. Test distribution is Normal.

Kolmogorov Smirnov is a commonly used normality testing, especially with the proliferation of numerous statistical programs. The advantages of this test are that it is simple and does not cause differences in perception between observers, which is the case for normality test using graphs. Results of KolmogorovSmirnov test depicted in Table 5 show significance values of children's socio-emotional skills during pretest at 0.670 , while during post-test at 0.176 . These mean that the residuals follow the normal distribution pattern as the result of Kolmogorov-Smirnov significance test is $>0.05(0.670>0.05)$ and $(0.176>$ 
0.05). Based on these, these data are worth testing using the Moment Product Correlation test.

Calculations for analyses of the effect of Bentengan game on children's socio-emotional development at TK Al Maghfiroh Semarang were tested using the Moment Product Correlation test with the following results:

Table 6. Results of Moment Product Correlation test.

\begin{tabular}{|c|c|r|r|}
\hline \multicolumn{4}{|c|}{ Correlations } \\
\hline \multirow{3}{*}{ Activities } & & activities & Soc-em. \\
\cline { 2 - 4 } & Pearson Correlation & 1 & $.773^{* *}$ \\
\cline { 2 - 4 } & Sig. (2-tailed) & & .000 \\
\cline { 2 - 4 } Soc-em & $\mathrm{N}$ & 30 & 30 \\
\cline { 2 - 4 } & Pearson Correlation & $.773^{* *}$ & 1 \\
\cline { 2 - 4 } & Sig. (2-tailed) & .000 & \\
\cline { 2 - 4 } & $\mathrm{N}$ & 30 & 30 \\
\hline
\end{tabular}

**. Correlation is significant at the 0.01 level (2-tailed).

Comparisons between calculated $r$ and table $r$ as displayed in Table 6 has significance level of $\square$ for both sides test at $5 \%, \mathrm{~N}=30$, with table $\mathrm{r}$ at 0.361 (see the statistics table for critical $\mathrm{r}$ at 5\%, appendix). Compared to calculated $\mathrm{r}$ at $0.773>0.361$, it is evident that calculated $r>$ than table $r$ and that the probable calculated $r$ is $0.000<0.05$. It this then concluded that there is a significant relationships between Betengan game and socio-emotional skills development in children at $\mathrm{TK} \mathrm{Al}$ Maghfiroh Semarang.

The level of influence of Betengan game on the development of socio-emotional skills is evident with calculated $\mathrm{r} 2=0.773 \times 0.773=0.597$ or $59.7 \%$. This means that $\mathrm{r} 2$ is the determining factor and significantly contributes to socio-emotional skills development in children at $\mathrm{TK} \mathrm{Al}$ Maghfiroh Semarang.

\section{REFERENCES}

[1] Dimyati. 1989. Psikologi Suatu Pengantar. Jakarta: Departemen Pendidikan dan Kebudayaan Direktorat Jenderal Pendidikan Tinggi Proyek Pengembangan Lembaga Pendidikan Tenaga Kependidikan.

[2] Ramayulis, Metodologi Pendidikan Agama Islam (Jakarta: Kalam Mulia, 2005).

[3] Muhibin, S. 2009. Psikologi Belajar. Ciputat: Logos.

[4] Desmareza, Rini. 2012. Peningkatan Perkembangan Sosial Emosional Anak Melalui Permainan Montase di RA Darul 'Ulum PGAI Padang. Padang: UNP.

[5] Yusuf, Ismed. 2007. Tumbuh Kembang Potensi dan Prestasi Anak Pra Sekolah. Semarang: Yayasan Kesehatan Jiwa Fatwa.

[6] Goleman, D. 2005. Emotional Intellegence. Jakarta : Gramedia.

[7] Hurlock, Elizabeth. B. 2009. Perkembangan Anak. Jakarta : Erlangga.

8] Lestari, Dwi Nur. 2014. Identifikasi Karakter Kindness Dalam Permainan Tradisional di TK Lab School UPI Bandung. BandungL Universitas Pendidikan Indonesia.

[9] Kartono, Kartini. 2005. Psikologi Anak (Psikologi Perkembangan). Bandung: CV Mandar Maju.

[10] Winn, Marie \& Mary Ann Porcher. 2006. Play Group, Kelompok Bermain yang Tepat Guna dan Tepat Sasaran. Semarang: Effhar Offset

[11] Sugiyono. 2014. Metode Penelitian Kuantitatif, kualitatif \& RND. Bandung: Alfabeta.

[12] Hoffman, Martin L. 2008. Empathic emotions and justice in society Intelligent Virtual Agents Lecture Notes in Computer Science. Social Justice Research (5) 2008:37-44

[13] Johansson, Eva. 2010. The preschool child of today - The world-citizen of tomorrow? International Journal of Early Childhood, Volume 41 (2) 79-95 